УДК 323.2-053.81

DOI https://doi.org/10.32838/TNU-2663-6468/2021.4/13

\title{
Стукан T.M.
}

Херсонський державний аграрно-економічний університет

\section{АНАЛІЗ ЄВРОПЕЙСЬКОЇ СИСТЕМИ ІНСТИТУЦІЙНОГО ЗАБЕЗПЕЧЕННЯ МОЛОДІЖНОЇ ПОЛІТИКИ}

\begin{abstract}
У статті здійснений аналіз інституиійних засад щодо формування молодіжної політики у краӥнах Європи. Сформована та наведена загальна інституційна структура Ради Свропи, яка відповідає за впровадження засад роботи з молоддю. Досліджено, через які формальні $і$ неформальні органи влади відбувається формування, реалізація та просування молодіжної політики. Класифіковано краӥни Європи щодо їх досвіду створення та функиіонування на державному рівні структур, які відповідають за проведення роботи серед вікової категорії до 34 років. Проаналізовано та згруповано краӥни у відповідності до інституиійне забезпечення та програм підтримки молоді. Визначено, що більмість європейських крайн мають сформовані дієві виконавчі органи, на які покладено формування та реалізачія молодіжної політики. Інституиійне забезпечення молодіжної політик в країнах Європи також характеризується постійними трансформачіями у відповідності до змін потреб молоді, розгалуженістю систем спеціалізованих на молодіжній політиці органів і в включенням иього сектору суміжних сфер: освіта, спорт, сочіальна сфера тощо. Аналізуючи структуру забезпечення молодіжної сфери державам притаманні і спільні риси, що реалізуються ними в даній галузі, вони включають: активне залучення молоді до всіх прочесів, щяо відбуваються в країнах, приділясться особлива увага соиіально вразливим категоріям молоді, здійснюється захист прав та свобод молодих людей иляхом просвітницької діяльності та створення відповідних інституцій. У статті наведені першочергові кроки, які слід зробити на шляху до імплементації проєвропейського досвіду у вітчизняну молодіжну політику. Дістало підтвердження, що інституиійне забезпечення в країні формує створення необхідних умов для самореалізації молоді та їх активного включення до суспільних та державних прочесів. Інституиійне забезпечення молодіжної політики в країні має створювати необхідні умови для самореалізаиї молоді та її активного включення в суспільні прочеси. Це дозволить забезпечити соиіальне, культурне $i$ економічне відтворення і прискорити суспільний розвиток.
\end{abstract}

Ключові слова: молодіжна політика, інституційна структура, імплементація, молодіжний фонд, недержавні інституиії, неформальні органи влади.

Постановка проблеми. Молодь сьогодні важливий людський ресурс в країні, від якого залежить майбутне держави та ії розвиток. У цьому контексті виникає необхідність зі сторони всіх рівнів влади визначитися із стратегічними і дієвими напрямами молодіжної політики, що сприятимуть поступовому становленню молодого покоління. Цього можливо досягти через консолідоване об'єднання зусиль, з метою вивчення досвіду європейських країн $з$ цього питання та забезпечення створення дієвого інституційного механізму, який спроможний надати прогресивний вектор розвитку молодіжного руху в країні. Набуття конкурентних переваг молоді відбувається через формування у даної категорії людей активної життєвої позиції, створення умов щодо зростання попиту на освіту, підвищення внутрішньої мобільності стосовно зміни місця роботи, перекваліфікації, освоєння нових видів і сфер діяльності, саме дані фактори та рівень їх дієвості в країні впливає на те, наскільки інституційне розгалуження в напрямі молодіжної політики має бути насиченим. На сьогодні для вікової категорії осіб до 34 років $є$ важливим формування комфортного середовища для життя та розвитку, пріоритетними напрямами для їх реалізації $\epsilon$ фінансове та кадрове забезпечення, розвиток молодіжної інфраструктури й залучення до процесу розроблення, ухвалення рішень та контролю за їх виконанням. Тому для розширення напрямів роботи та напрацювання єдиного проєвропейського механізму в сфері молодіжної політики перш за все слід проаналізувати інституційне забезпечення, яке на сьогодні існує в країнах Європи, для того, щоб виокремити кращі практики, які стануть основою створення нових шляхів у просуванні молодіжного вектору розвитку. Формування інституційної структури також дозволить розширити сфери впливу молоді, 
адже на сьогодні надання додаткових можливостей молодим людям впливати на питання, які стосуються їхнього життя через участь у прийняття рішень, є необхідним, що створить 3 їх сторони зацікавленість та приверне інтерес до вирішення питань загальнодержавного рівня.

Аналіз останніх досліджень і публікацій. 3 тим, як швидко змінюється соціальне, культурне, економічне життя в країнах, виникає необхідність переорієнтації діяльності за ключовими напрямами, і молодіжна політика у цьому не $є$ винятком. Питанням ролі молоді в державотворенні вчені займаються протягом тривалого часу, вони досліджують фактори та чинники пливу на цей процес і намагаються знайти дієві механізми щодо налагодження цих процесів у відповідності до реалій, які нам диктує сьогодення. Теоретичний аспект в плані формування молодіжної політики досліджений такими науковцями: С. Бородіним, Д. Андрєєвим, О. Німко; К. Захаренко, М. Перепелицею та С. Цибіним. Проблемні питання реалізації молодіжної політики розглянуті в працях: О. Амосова, А. Баранової, А. Васильєва, Г. Коваля, Л. Кривачука, О. Кулініча, Ю. Куца, Н. Метьолкіної, В. Омельчука та ін. Вивченням досвіду зарубіжних країн займалися такі вчені, як С. Бородін, Ю. Борисова, Н. Літвінова, І. Хохрякова та ін. Залишається гостра необхідність та актуальне питання щодо дослідження європейського досвіду для формування дієвих напрямів розвитку молодіжної політики з метою подальшої імплементації кращих практик до українських реалій.

Формулювання цілей статті. Метою статті $\epsilon$ вивчення та проведення аналізу особливостей європейської структури інституційного забезпечення молодіжної політики з метою імплементації їх досвіду в Україні.

Виклад основного матеріалу дослідження. Зараз молодь стикається 3 низкою проблем та перепон, серед них - зростання безробіття, недостатній рівень заробітної плати, недосконала законодавча база та інституційне забезпечення у сфері молодіжної політики. А обравши проєвропейський розвиток за всіма напрямами, включаючи і формування загальнонаціональної молодіжної політики, першочергово виникає потреба у становленні дієвого механізму інституційного забезпечення на прикладі країн Свропи, що відповідала б вимогам сьогодення. Тому для дослідження було обрано вивчення європейського досвіду щодо створення стратегічного плану реалізації молодіжної політики та аналіз провладних інституцій, які безпосередньо відповідають за ці процеси. До основних структур Європейської ради, що відповідають за молодіжний напрям, відносять: Директорат з питань молоді та спорту, статутні органи, Європейські молодіжні центри та Європейський молодіжний фонд всі вони безпосередньо підпорядковуються Раді Свропі (рис. 1). Перераховані сфери мають свою сферу відповідальності та впливу у сфері проведення молодіжної роботи щодо виконання окреслених завдань та намічених стратегічних цілей.

Директорат 3 питань молоді та спорту функціонально безпосередньо підпорядковується Раді Європи, є підрозділом Генерального директорату 3 питань освіти, культури і спадщини, молоді i спорту, та його діяльність як вищого колегіального органу направлена на координацію зусиль країн СС в напрямі реалізації молодіжної політики. Директорат визначає базові стратегії, розробляє програми та законодавчі акти, згідно з якими відбуватиметься поетапний, цілісний та ефективний розвиток та впровадження молодіжної політики в країнах на 3-х рівнях: місцевому, національному і європейському. До його функціоналу також входить фінансова та освітня підтримка молодіжної діяльності за такими напрямами, як мобільність, захист прав, демократія та соціокультурне забезпечення.

Директорат проводить дослідження щодо соціального становища молоді, їхніх життєвих стратегій і планів стосовно самореалізації та здійснює поширення отриманих результатів аналітичноекспертної діяльності. На Директорат також покладені Радою Європи обов'язки, що стосуються забезпечення пріоритетних напрямів молодіжної політики, серед яких [1]:

- освіта у сфері прав людини;

- безпосередня участь молоді у реалізації молодіжно політики у всіх її аспектах та демократичне громадянство;

- залучення молоді до суспільного життя;

- розвиток молодіжної політики.

Освіта у сфері прав людини направлена на виховання у молоді почуття солідарності, толерантності, здатності до мирного розв'язання конфліктів, поваги до культурних особливостей та традицій інших. Тому в цьому плані країни $\mathrm{CC}$ розвивають діяльність тренерів, які компетентні в питаннях прав людини для роботи в молодіжному середовищі, можуть підтримувати та допомогти у впровадженні досвіду на місцевому рівні, в системі формальної та неформальної освіти. Безпосередня участь молоді у реалізації молодіжно політики у всіх її аспектах та демократичне громадянство передбачає здійснення роботи в напрямі 


\section{РАДА ЄВРОПИ}

Генеральний директорат з питань освіти, культури і спадщини, молоді і спорту

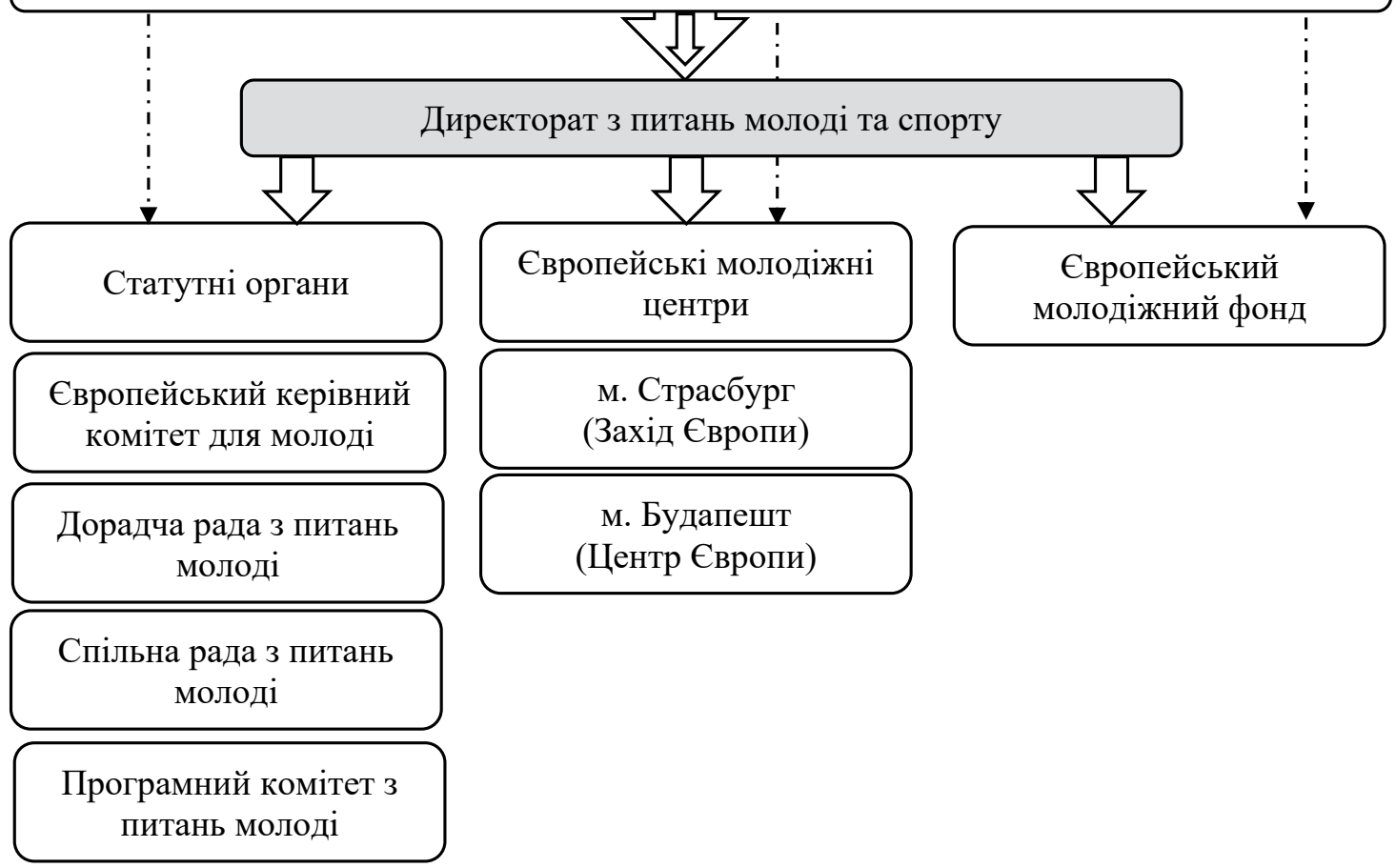

Рис. 1. Загальна інституційна структура Ради Європи, яка направлена на впровадження молодіжної політики

Джерело: сформовано автором за даними [1]

підвищення значимості молодіжних організацій, об'єднань, розвитку громадської активності, громадянської освіти, а також залучення молоді до прийняття важливих державних рішень. Під залученням молоді до суспільного життя мається на увазі їх доступ до участі у створенні життєвих та соціальних прав, розробці заходів, що направлені на розвиток молодіжної політики та громадянської відповідальності. Під розвитком молодіжної політики розуміється врахування всіх недоліків в попередній роботі та формування стандартів, виокремлення підходів до роботи 3 молоддю, посилення діяльності, направленої на висвітлення актуальності неформальної освіти, а також це підтримка якісних показників та стабільності впровадження європейських програм та проєктів, направлених на посилення пріоритетності та актуальності молодіжної політики, з урахуванням кваліфікаційної підготовки молодіжних кадрів.

Європейський керівний комітет для молоді являє собою об'єднання центральних органів влади країн у сфері молодіжної політики. До функцій Комітету також входить визначення критеріїв щодо порівняння національних моделей моло- діжної політики, встановлення обміну досвідом 3 питань реалізації та введення кращих практик. До їх компетенції відноситься виконання рекомендацій Ради Свропи в частині виконання принципів і напрямів молодіжної політики, свідомий розвиток громадянського суспільства та виконання Конвенції про міжнародну добровільну допомогу молоді. Комітет займається організацією та проведенням конференції серед країн-членів, даний захід покликаний налагодити дієвий механізм в частині обміну інформацією стосовно основних пріоритетів молодіжної політики, формування правових інструментів іiі регулювання на рівні держави та обговорення заходів щодо активного долучення молоді до процесів молодіжної політики.

Дорадча рада 3 питань молоді у своєму складі має 30 представників неурядових молодіжних організацій та об'єднань. У діяльності враховує точку зору молодіжних громадських організацій 3 питань молодіжної проблематики для формування та прийняття рішень щодо вирішення проблемних питань на рівні Ради Європи.

Спільна рада з питань молоді об'єднує та координує діяльність між Європейським керівним 
комітетом для молоді та Дорадчою радою з питань молоді. Взаємодія між зазначеними структурами відбувається на спільному засіданні представників. На зібрані визначаються з гострими молодіжними проблемами, пріоритетністю щодо їх вирішення та з обсягами фінансування. Дана модель взаємодії дозволяє знайти паритетність між загальнодержавними структурами та молодіжним сегментом. До компетенцій програмного комітету 3 питань молоді входить здійснення розробки, проведення моніторингу та оцінки програм Європейських молодіжних центрів і Європейського молодіжного фонду, до його складу входить по вісім представників від кожної із структур.

Європейські молодіжні центри створені у двох містах. Це Страсбург, що географічно покриває західну частину Європи, та Будапешт - Центральна Європа. Ці структури направлені на забезпечення реалізації молодіжної політики визначеної Радою Європи на місцях. Завдяки ним відбувається систематичне проведення міжнародних конференцій, зустрічей з молодіжних питань, вони координують реалізацію молодіжних проєктів в країна, здійснюють забезпечення освітньої, інформаційної та технічної складової щодо супроводу в підготовці, розробці та впровадженні проєктів, що фінансуються Радою Європи. Але якщо послуги даних Центрів необхідні європейським країнам та іншим суб'єктам молодіжної політики, то вони можуть ними скористуватися на умовах самофінансування.

Діяльність Європейського молодіжного фонду направлена на фінансове забезпечення європейської молодіжної політики. Рада Європи щорічно передбачає для діяльності Фонду суму у розмірі 2,5 млн євро, з обсягу якої відбувається підтримка різного роду молодіжних заходів, які ініціюють громадські об'єднання та молодіжні організації країн $€ С$, до цього переліку входить фінансування на проведення конференцій, зустрічей, акцій, значні кошти спрямовуються на популяризацію молодіжного руху і виділяються для публікацій, на виготовлення аудіо- та відеопродукції, створення веб-сайтів, сторінки в соціальних мережах тощо. Крім загальнодержавних програм, Європейський молодіжний фонд фінансує гранти на розвиток міжнародних неурядових молодіжних організацій та їх об'єднань. 3 початку існування Фонд забезпечив фінансовою підтримкою понад 300 тис. молодих громадян європейських країн, з початку XXI століття підтримувати щорічно більше ніж 10 тис. молодих людей.

До інших інституційних структур Європейського Союзу, діяльність яких направлена на забез- печення розвитку молодіжної політики в країнах, відносять Свропейську Комісію, Директорат «Д» (Молодь, спорт та зв'язки 3 громадянами), який має такі підрозділи 3 питань: молодіжної політики; молодіжних програм; спорту; громадянського суспільства, партнерства та зв'язків.

Директорат з питань освіти та культури та його підрозділи мають у своїй діяльності ряд визначених пріоритетних аспектів [1]:

1) створення в країнах $€ С$ найміцнішої у світі економіки знань, здатної забезпечити найкращі умови праці та надійну соціальну підтримку;

2) розвиток європейської культури;

3) залучення громадян до процесу євроінтеграції.Також спільно Радою Європи та Європейським Союзом було створено ще одну структуру, діяльність якої направлена на здійснення інформаційно-аналітичній заходів у сфері молодіжної політики - це Європейський центр знань 3 молодіжної політики. Ця установа забезпечує обмін досвідом між країнами Свропи в напрямі молодіжної роботи, сприяє практичному втіленню результатів досліджень, визначає основні пріоритетні позиції молодіжної політики, здійснює моніторинг, накопичення та систематизацію інформації щодо волонтерської активності молоді, їі взаємодії з громадськими організаціями, молодіжними центрами тощо.

Інституційне забезпечення щодо програм підтримки молоді розділяє країни Європи на три групи. Перша - це держави, в яких молодіжний сектор достатньо представлений (Австрія, Люксембург, Ліхтенштейн, Німеччина, Іспанія, Греція, Португалія), до другої групи відносяться країни, де починається створення молодіжних секторів (Нідерланди, Франція, Бельгія, Ірландія, Фінляндія, Швеція, Норвегія). Третя група - країни, у яких відсутній окремий молодіжний сектор як структура (Великобританія, Італія, Данія).

Європа має 18 країн, які можуть ділитися досвідом стосовно створення молодіжних міністерств та департаментів. Ці держави класифіковано за чотирма ознаками [1]:

1) країни 3 молодіжним міністерством та молодіжним директоратом - Німеччина, Австрія, Люксембург, Франція;

2) країни, де молодіжна політика віднесена до одного з міністерств, у складі якого є молодіжний департамент (Швеція, Ірландія, Португалія, Греція, Іспанія, Бельгія, Нідерланди, Фінляндія, Норвегія);

3) країни, в яких молодіжна політика координується декількома міністерствами без молодіжного директорату (Данія); 
4) країни без молодіжних директоратів та спеціальних координуючих структур в органах виконавчої влади (Італія, Великобританія).

Отже, 3 проведеного аналізу можна зробити висновок, що більшість європейських країн мають сформоване інституційне забезпечення, виконавчі органи, на які покладено формування та реалізація державної у сфері молодіжної політики. По окремим країнам існують Міністерства, де з його назви вже зрозуміло, що до кола його функціональних обов'язків входить створення умов, налагодження процесів щодо розвитку та популяризації молодіжного руху. Так, для прикладу, перелік країн з сформованими Міністерствами [1]:

1) Міністерство $з$ питань молоді і спорту Франція, Болгарія, Азербайджан, Туреччина, Македонія;

2) Міністерство освіти, молоді та спорту Чехія, Молдова, Монако;

3) Міністерство культури та у справах молодіВірменія;

4) Міністерство туризму, культури, молоді i спорту - Албанія;

5) Міністерство у справах сім’ї, літніх громадян, жінок та молоді - Німеччина;

6) Міністерство молоді, сім'ї, соціальної допомоги та рівних можливостей - Угорщина;

7) Міністерство освіти, молоді га зайнятості Мальта;

8) Міністерство молоді та спорту України Україна.

Для прикладу розглянемо, як впроваджується молодіжна політики в таких країнах, як Швеція, Румунія, Нідерланди, Кіпр, Іспанія, Мальта, Фінляндія. У Швеції молодіжні питання на загальнодержавному рівні координує Міністерство освіти, досліджень та культури. Управління у сфері молодіжної політики здійснюється на місцях, центральними органами влади 3 питань освіти, здоров'я, внутрішніх справ. Об'єктивний контроль за здійсненою роботою, виконанням завдань за визначеним напрямами проводить створена при Міністерстві незалежна комісія. Можна говорити, що країна має вертикальну інституційну структуру щодо здійснення молодіжної політики, та існують чіткі, зрозуміли методи контролю за процесами реалізації.

Румунія для просування даної сфери створила таку інституцію, як Національна владна структура для молоді Генеральної дирекції програм і міжнародних відносин. На дану структуру покладені такі завдання: здійснення координації при проведенні заходів у рамках молодіжної політики, збір інформації з питань іiі реалізації, ведення законотворчої діяльність в окресленому напрямі. Водночас в Румунії паралельно діють й інші інституції, на як покладені функції щодо розробки та впровадження нових напрямів молодіжної політики. Працює також і Департамент молодіжної політики, основна функція - координація діяльності всіх інституцій, залучених до вирішення проблемних питань у молодіжній сфері.

У Нідерландах не має окремо Міністерства, у них створений Департамент молодіжної політики, який перебуває у підпорядкуванні Міністерства охорони здоров'я, добробуту та спорту. Також створений Центральний молодіжний офіс, який займається розповсюдженням та впровадженням програмних положень молодіжної політики на місцях (регіонах) і здійснює профілактичну роботу в молодіжному середовищі. У Нідерландах також створені та діють недержавні інституції, які займаються систематизацією, популяризацією та розповсюдженням через різні канали комунікації інформації стосовно молодіжних програм, заходів, ініціатив, висвітлюють проблемні питання у молодіжній сфері. На місцях в даній країні створені регіональні альянси, інформаційні пункти для молоді, які всім зацікавленим особам надають необхідну інформаційну та консультаційну допомогу.

Уряд Кіпру визначив, що за молодіжну політику на держаному рівні відповідає Молодіжний Департамент. До кола функціональних обов'язків входить формування пропозицій та надання рекомендацій стосовно розробки молодіжної політики на законодавчому рівні, створення та впровадження програм підтримки молодіжного руху. Даний департамент також виконує дорадчу, координаційну та виконавчу функції в питаннях, пов'язаних із розробкою та впровадженням політики щодо вікової категорії до 34 років. У своєму складі Молодіжний Департамент має такі структурні підрозділи (дорадчі комітети): політичний молодіжний комітет, консультативний орган профспілок та центральний консультативний орган. Остання інституція займається недержавними молодіжними об'єднаннями, організаціями, які зацікавлені та беруть участь у заходах, що організовує Молодіжний Департамент. На місцях для більш ефективного розповсюдження молодіжної політики на Кіпрі є практика створення Комітетів студентів, які представляють інтереси молоді, що навчається в середній школі, коледжах та університетах.

Іспанія просування молодіжної політики в країні здійснює через вертикальну структуру 
загальнодержавних інституцій - Міністерство праці та соціальних питань, Національний інститут молоді, Міжвідомчий комітет дитинства та молоді. Загальна мета цих трьох органів - впровадження заходів комплексного молодіжного плану у сфері молодіжної політики. Національний інститут молоді - діяльність направлена на просування єдиної стратегії та плану дій стосовно молодіжної роботи в усіх регіонах країни. Допомагають даній інституції реалізовувати молодіжну політику на місцях громади, міські ради, ради молоді та молодіжні асоціації. Головна функція Національного інституту молоді - координаційна, директор цієї інституції $є$ і державним секретарем Міністерства праці та соціальних питань.

Уряд Мальти у своєму підпорядкуванні має Міністерство молоді та мистецтв, де у функціональних обов'язках закладено здійснення виконавчих функцій, направлених на реалізацію молодіжної політики в країні. Також створена ще одна інституційна структура, яка здійснює забезпечення консультаційної діяльності стосовно формування та впровадження заходів направлених на покращення роботи в молодіжній сфері - Національна Рада молоді. Тобто через ці дві основні структури формують передумови для прогресивного розвитку молодіжної політики на Мальті.

Діяльність у сфері молодіжної політики та все, що пов'язано з категорією осіб до 34 років, у Фінляндії лежить у функціональній сфері Міністерства освіти. Що стосується житлових умов молоді, то даний напрям належить до компетенції різних адміністративних секторів. Фінляндія замість Національної молодіжної ради створила Дорадчу раду у справах молоді, які має у своій структурі і 3 підкомітети: 3 питань освіти та зайнятості; 3 питань житла і доходів; 3 питань громадської активності. На Дорадчу раду покладені такі функціональні обов'язки, як внесення пропозицій щодо фінансування заходів молодіжної політики; допомага міністерствам, відповідальним за ті чи інші аспекти життя молоді; сприяння у формуванні та економічному обгрунтування програм діяльності молодіжних організацій. Також Фінляндія має ще одну інституційну структуру національну службу з назвою Агенція співробітництва фінської молоді, яка займається наданням інформаційних послуг для молоді, фахівцям по роботі з молоддю, а також для підготовки публікацій та складання звітів, сприяє проведенню просвітницьких акцій з питань безробіття, пошуку першого робочого місця, вибору спеціальності тощо. Агенція здійснює вивчення й розповсю- дження корисного досвіду розв'язання проблем в ювенальній сфері. Веде співпрацю зі службами 3 роботи $з$ молоддю, освітніми установами, урядом та Дорадчою радою у справах молоді та виступає комунікаційним каналом між молоддю та урядом. Через функціонування трьох державних органів у Фінляндії відбувається процес реалізації молодіжної політики на загальнодержавному рівні.

Отже, із проаналізованих структур інституційного забезпечення в європейських країнах немає чіткої молодіжної політики, єдиної для всього Європейського Союзу. Уряди країн Свропи створюють Міністерства, діяльність яких направлена на забезпечення формування та просування молодіжної політики. Убачається, що в більшості своїй ці Міністерства не однопрофільні, тобто не мають виключно молодіжної спрямованості. Аналіз молодіжної політики в Свропі від країни до країни показує, що вона відрізняється, починаючи від фінансового забезпечення до розгалуженості структури на місцях і проникнення до найвіддаленіших регіонів.

Тому якщо імплементувати досвід європейських країн на території України, то слід відразу створювати однопрофільне Міністерство, діяльність якого буде направлена виключно на молодіжний сегмент, на розуміння молодіжної проблематики, їх зайнятості, сприяння участі у соціальному, економічному, політичному житті країни. Також на дану інституцію покладається функція з розробки та реалізації молодіжних проєктів, програм, конкурсів, в яких вікова категорія до 34 років може взяти участь і тим самим розкрити свої здібності, навички і здобути нові для себе компетенції.

Діяльність Міністерства розпочинається 3 низки нормативних актів, які будуть зумовлювати роботу в сфері молодіжної політики в межах правового поля. Тим самим спонукати молодь бути активним, зацікавленим учасником вирішення завдань, що стоять перед суспільством. Інституційне забезпечення молодіжної політики в країні має створювати необхідні умови для самореалізації молоді та іiі активного включення в суспільні процеси. Це дозволить забезпечити соціальне, культурне і економічне відтворення і прискорити суспільний розвиток.

Сьогодні національна молодіжна політика потребує змін в управлінні молодіжної сферою, створенні загальнодержавних інституцій, які відповідатимуть за реалізацію молодіжної політики та сприятимуть формуванню актуальних завдань, що направлені на створення необхідних 
умов формування ефективної молодіжної політики. Тому новим вектором розвитку молодіжної політики в Україні все ж таки є співпраця національних молодіжних організацій і структур 3 європейськими інституціями Ради Європи відповідальними за молодіжну сферу. Така взаємодія може зміцнити подальший розвиток співпраці 3 країнами Європи, а також розширить можливості для участі України в програмах, заходах та проєктах, що реалізуються Радою Європи.

Починаючи з 2018 року в Україні почалася імплементація досвіду європейських країн в молодіжній сфері, i цьому підтвердженням $€$ проєкт «Молодь за демократію в Україні», який реалізується у межах Плану дій Ради Свропи для України на 2018-2022 роки. Даний проєкт передбачає співпрацю з органами місцевої влади та молодіжними організаціями 3 метою посилення участі молоді й громадської активності як у селах, так і в містах України в розвитку та просуванні молодіжної політики в країні. Це можна реалізувати через об'єднання спільних зусиль зацікавлених сторін та підвищення якості молодіжної політики й роботи з молоддю згідно зі стандартами Ради Європи. У рамках даного проєкту планується активізувати молодіжні центри та молодіжну роботу у всіх регіонах України. У рамках запуску пілотної схеми це буду реалізовано серед 12 перших центрів, які виявлять бажання взяти участь у процесі. Метою є заохочення молодіжних центрів до перегляду підходів до реалізації власних стратегії, що в першу чергу задовольняли б потреби молодих людей та відповідали стандартам Ради Свропи з молодіжної громадської участі та молодіжної роботи. Відібрані молодіжні центри зможуть $[2,3]$ :

1) здійснити аналіз стану молодіжної роботи та програм неформальної освіти;

2) запропонувати команди 3 трьох учасників (адміністративний персонал, відповідальні за напрям освіти, молодіжні працівники та працівниці), які візьмуть участь у тривалому процесі навчання;

3) взяти участь у практичних семінарах 3 найкращих практик та стандартів Ради Європи та отримати інституційну та освітню підтримку для підготовки стратегії щодо переформатування роботи та принципів діяльності у молодіжному центрі;

4) долучитися до розроблення низки рекомендацій щодо національних стандартів стосовно молодіжних центрів/просторів на основі отриманого досвіду;
5) спільно навчатись та розбудовувати співпрацю 3 молодіжними центрами 3 різних регіонів України.

Висновки. Аналіз європейського досвіду інституційного забезпечення молодіжної політики у країнах показав, що дієва робота в напрямі розвитку молодіжної сфери відбувається виходячи зі сформованої вертикальної структури, де існує чітке делегування повноважень та контроль виконання поставлених завдань 3 метою досягнення як короткострокових, так $\mathrm{i}$ довгострокових цілей. Вбачається, що доцільним $є$ створення однопрофільних Міністерств, які будуть опікуватися лише молодіжною політикою в країні та не розсіюватися на інші функціональні обов'язки різних сфер. Інституційне забезпечення держав повинно займатися, окрім просування молодіжних програм, заходів і вирішення проблем, ще й забезпеченням здобуття неформальної освіти, знань, вмінь, навичок та компетентностей, які сформують конкурентні переваги у людини та створять додаткові можливості для пошуку бажаного місця роботи на ринку праці. Встановлено, що європейські країни мають у сфері молодіжної політки різні підходи як до процесу створення провладних структур, так і до визначення пріоритетних напрямів розвитку цієї сфери. У своєму баченні роботи 3 молодіжним сегментом одні ведуть роботу щодо гарантії прав незахищених представників молоді, надання послуг та опосередковано втручаються в те, що відбувається на молодіжному рівні в країні, інші ж активно співпрацюють 3 усіма суб'єктами: молодіжними організаціями, формуваннями, об'єднаннями тощо для більш ефективного створення, просування та реалізації молодіжної політики. Інституційне забезпечення молодіжної політик в країнах Свропи також характеризується постійними трансформаціями у відповідності до змін потреб молоді, розгалуженістю систем спеціалізованих на молодіжній політиці органів і в включенням цього сектору суміжних сфер: освіта, спорт, соціальна сфера тощо. Водночас державам притаманні і спільні риси, що реалізуються ними в даній галузі, вони включають: активне залучення молоді до всіх процесів, що відбуваються в країнах, приділяється особлива увага соціально вразливим категоріям молоді, здійснюється захист прав та свобод молодих людей шляхом просвітницької діяльності та створення відповідних інституцій.

Якщо імплементувати в Україні досвід країн Європи, то доцільно обрати інституційну модель Фінляндії, де є чітко сформована законодавча база, 
розгалужена структура органів, до функціональних обов'язків яких належить діяльність, пов'язана 3 формуванням, забезпеченням та реалізацією молодіжної політики, та наявний потужний потенціал громадських молодіжних організацій. За фінською моделлю доцільним буде створити сьогодні в Україні в кожній області Молодіжні комісії, які будуть виконувати провладні функції та займатимуться активним залученням молоді до державно-управлінської діяльності в регіоні або навіть у країні. На сьогодні ті Молодіжні ради, що створені при кожних міських та обласних адміністраціях, виконують лише дорадчі функції та використовуються як інформаційний ресурс взаємодії державних органів, громадських організацій з органами студентського самоврядування. Тому є необхідність створення на місцевих рівнях молодіжних державних інституцій, які будуть активно працювати та реалізовувати завдання, які на них покладені в рамках державної молодіжної політики.

\section{Список літератури:}

1. Бородін Є.І., Борисова Ю.В., Літвінова Н.М., Хохрякова І.В. Сучасний європейський досвід формування та реалізації молодіжної політики : навч. посіб. Дніпро : Пороги, 2008. 116 с.

2. Відбулась подія офіційного запуску проєкту «Молодь за демократію в Україні». URL : https://www. coe.int/uk/web/kyiv/-/the-official-launch-of-the-project-youth-for-democracy-in-ukraine-took-place (дата звернення 04.04.2021).

3. Проєкт Ради Європи «Молодь за демократію в Україні» запрошує молодіжні центри України до партнерства. URL : https://www.coe.int/uk/web/kyiv/-/project-of-the-council-of-europe-youth-for-democracyin-ukraine-invites-for-partnerships-with-youth-centers-in-ukraine (дата звернення 04.04.2021).

4. Стукан Т.М. Особливості зайнятості молоді в Україні. Міжнародний науковий журнал «Iнтернаука». Серія: «Економічні науки». Випуск № 7(39)/2020. C. 77-85. URL : https://doi.org/ $10.25313 / 2520-2294-2020-7-6181$.

5. Стукан Т. Молодіжна політика: суть, основні принципи та стан реалізації в Україні. Таврійський науковий вісник. Серія: Економіка. Випуск № 4. 2020. С. 125-131.

6. Формування та реалізація державної молодіжної політики в Україні в умовах децентралізації. Тернопіль : ТОВ «Тернограф», 2017. 100 с.

7. Yurii Kyrylov, Natalia Kyrychenko, Tatyana Stukan and Hanna Zhosan, Formation of Enterprise. Management Strategies and Entrepreneurship Training, International Journal of Management. 2020. № 11(6). P. 793-800. URL: http://www.iaeme.com/MasterAdmin/Journal_uploads/ijm/VOLUME_11_ISSUE_6/ IJM_11_06_067.pdf (дата звернення: 04.04.2021).

\section{Stukan T.M. ANALYSIS OF THE EUROPEAN SYSTEM OF INSTITUTIONAL SUPPORT FOR YOUTH POLICY}

The article analyzes the institutional framework for the formation of youth policy in European countries. The general institutional structure of the Council of Europe, which is responsible for the implementation of the principles of work with youth, has been formed and presented. It is investigated through which formal and informal authorities the formation, implementation and promotion of youth policy takes place. European countries are classified according to their experience in creating and operating at the state level structures responsible for work among the age group up to 34 years. Countries are analyzed and grouped according to institutional support and youth support programs. It is determined that most European countries have formed effective executive bodies, which are responsible for the formation and implementation of youth policy. Institutional support of youth policies in European countries is also characterized by constant transformations in accordance with changing needs of youth, extensive systems of bodies specialized in youth policy and the inclusion of related sectors in this sector: education, sports, social sphere and more. Analyzing the structure of youth provision, states have common features in common in this area, they include: active involvement of youth in all processes taking place in countries, special attention is paid to socially vulnerable categories of youth, protection of rights and freedoms of young people through education activities and the establishment of appropriate institutions. The article outlines the priority steps to be taken towards the implementation of the pro-European experience in domestic youth policy. It was confirmed that the institutional support in the country creates the necessary conditions for self-realization of young people and their active involvement in social and state processes. Institutional support of youth policy in the country should create the necessary conditions for self-realization of youth and its active inclusion in social processes. This will ensure social, cultural and economic reproduction and accelerate social development.

Key words: youth policy, institutional structure, implementation, youth fund, non-governmental institutions, informal authorities. 